\title{
RISK FACTORS FOR SCORPION STINGS IN THE BENI MELLAL PROVINCE OF MOROCCO
}

\author{
Charrab N (1), El Oufir R (2), Soulaymani A (1), Semlali I (2), Mokhtari A (1), \\ Soulaymani R (2)
}

(1) Laboratory of Genetics and Biometrics, Kenitra Faculty of Sciences, Ibn Tofail University, Kenitra, Morocco; (2) Poison Control and Pharmacovigilance Center of Morocco, Rabat Institute, Madinat Al Irfane, Rabat, Morocco.

\begin{abstract}
Scorpion stings comprise a serious problem throughout the globe, especially in regions where they are more frequent. In Morocco, Beni Mellal is one of the provinces most affected by this burden. This study aimed to trace the epidemiological profile of scorpion stings in Beni Mellal in order to improve patient care and prevent both morbidity and mortality. Our work is a retrospective study of scorpion stings based on medical charts of Beni Mellal. From 2002 to 2007, 8,340 cases were registered in this province with an average incidence of $1.36 \%$. The stings were more frequent in summer months, particularly July and August, and between 6 p.m. and 6 a.m. (59.8\%). The average age of victims was $26.54 \pm 18.42$ years. Children were affected in $30.3 \%$ of the cases. Of all registered cases, $67.3 \%$ of the patients received medical aid in less than an hour after the sting. The envenomation rate (Class II and Class III) was $12.4 \%$ and the overall case-fatality rate was $0.42 \%$ with a mortality rate of $0.005 \%$. Statistical analysis of the various studied factors revealed a significant connection among the envenomation class, patient age and evolution.
\end{abstract}

KEY WORDS: epidemiology, scorpion, register, Beni Mellal, Morocco.

CONFLICTS OF INTEREST: There is no conflict.

\section{CORRESPONDENCE TO:}

CHARRAB NEZHA, Laboratoire de Génétique et Biométrie, Département de Biologie, Faculté des Sciences, Université Ibn Tofail, BP 133, Kenitra 14000, Maroc. Fax: 002125373294 33. Email: charrabnezha@yahoo.fr. 


\section{INTRODUCTION}

Scorpions play an important role in severe cases of human envenomation in Morocco $(1,2)$. Epidemiological data compiled by the Poison Control and Pharmacovigilance Center of Morocco (CAPM) showed that scorpion stings are the leading cause of poisoning in Morocco with an incidence ranging from 0 to $2.9 \%$ and an overall casefatality rate of $0.36 \%$ up to $5.3 \%$ in some areas (3). Ninety percent of the fatal victims were younger than 15 years old (1). According to the data from the national strategy against scorpion stings, approximately 25,000 stung patients are recorded every year in Morocco (4).

There are more than 30 scorpion species in Morocco, but not all of them are dangerous to humans. The Moroccan province of Beni Mellal has high scorpion sting incidence and lethality and is known for its richness of scorpion species among which, those of the family Buthidae were the most implicated, in particular: Androctonus mauretanicus, Buthus occitanus and Hottentota franzwerneri.

The aims of the present study were: to investigate morbidity and mortality indicators using the records of the system Beni Mellal Province over six years (2002 to 2007); to describe the specific epidemiological map of this province and to define the factors having an influence on the evolution of stung people.

\section{PATIENTS AND METHODS}

This work is a retrospective epidemiological study of the scorpion sting cases from January 2002 to December 2007; recorded from the register specially designed by the CAPM and existing at the three health structures of the Beni Mellal medical delegation: polyclinic Fkih Ben Saleh, polyclinic Tadla and the provincial hospital (5). Beni Mellal province is located in the Tadla-Azilal region (central of Morocco), an area of $7,075 \mathrm{~km}^{2}$ with an estimated population of 983,000 inhabitants in 2002, 998,000 in $2003,1,012,000$ in 2004, 1,025,000 in 2005, 1,038,000 in 2006 and $1,047,000$ in 2007 . The climate is continental: cold in winter with a very hot summer. The register is a database of all cases of scorpion stings. It is completed by the doctor in charge of the patient and sent to the CAPM.

The study is based on a description of the study population and analysis of the influence of some factors studied (age and class of admission) on the two evolution subgroups: death and healing. 
The seizure and statistical analyses were conducted at the Genetics and Biometry Laboratory at Kenitra Faculty using the SPSS version 10.0; the statistical methodology was based on the following two pillars:

- as average, standard deviation is performed to determine the characteristics of each variable studied. The incidence is calculated by the ratio of the number of cases of scorpion sting in the population at risk population during the monitoring period. The lethality for each class is calculated by dividing the number of deaths in an age group by the total number of cases in the same age group;

- statistical analysis is based on the $\chi^{2}$ test by calculating the relative risk (RR) for age groups ( $\leq 15$ and $>15$ years) and admission classes.

\section{RESULTS}

During the study period, 35 deaths and 8,340 stings were recorded in this province.

\section{Incidence of Scorpion Stings According to Years}

From January 2002 to December 2007, 8,340 cases of scorpion sting are recorded in Beni Mellal province (Figure 1).

From 2002 to 2007 the maximum number of scorpion sting cases (1,924 cases), registered in 2006, coincided with the awareness campaign; the respective yearly incidences were: $0.85 \%, 1.22 \%, 1.11 \%, 1.8 \%, 1.85 \%$ and $1.31 \%$ with an average of $1.36 \%$. 


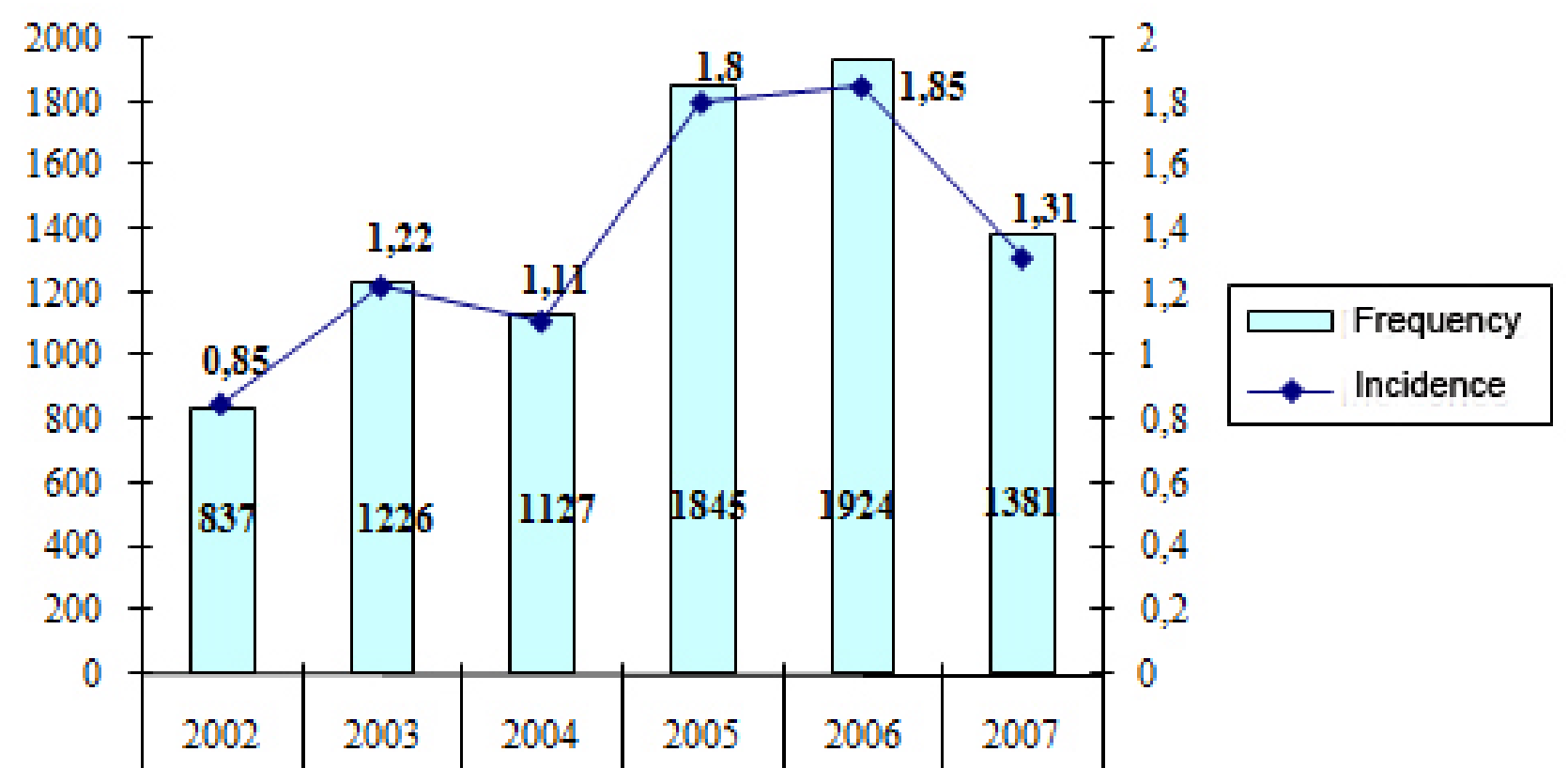

Figure 1. The distribution of scorpion stings by year.

\section{Epidemiological and Clinical Characteristics of Scorpionism}

Table 1 shows the characteristics of stung patients in the three health clinics: the polyclinics Fkih Ben Saleh, the polyclinics Tadla and the provincial hospital of Beni Mellal. 
Table 1. Characteristics of stung patients by health center

\begin{tabular}{l|c|c|c|c}
\hline & Fkih Ben Saleh & Tadla & Beni Mellal & Total \\
\hline Average age in years & $28.50 \pm 17.33^{*}$ & $29.04 \pm 18.31^{*}$ & $25.15 \pm 18.47^{*}$ & $26.54 \pm 18.42^{*}$ \\
$\%$ of children $\leq 15$ years & 21.33 & 25.74 & 38.11 & 30.35 \\
$\underline{\text { Sex }}$ & 1209 & 776 & 1869 & 3854 \\
Male & 1590 & 960 & 1936 & 4486 \\
Female & 0.76 & 0.80 & 0.96 & 0.85 \\
Sex ratio (M/F) & $1.46 \pm 1.79^{*}$ & $1.88 \pm 2.46^{*}$ & $1.59 \pm 1.81^{*}$ & $1.65 \pm 2.08^{*}$ \\
Average post-sting time & & & & \\
(hours) & & & & \\
Class of admission & 2706 & 1355 & 2607 & 6668 \\
Class I & 45 & 70 & 557 & 672 \\
Class II & 4 & 11 & 258 & 273 \\
Class III & 1409 & 850 & 2702 & 4961 \\
Evolution & 0 & 0 & 35 & 35 \\
Favorable & & & & \\
Death & & & & \\
\hline
\end{tabular}

*Standard deviation

These results showed that the average age of stung patients was $26.54 \pm 18.42$ years and that children $\leq 15$ years accounted for $21.33 \%$ in Fkih Ben Saleh, $25.74 \%$ in Tadla and $38.11 \%$ in Beni Mellal.

In the three health structures, the sex ratio favored females, because women are often in the outdoors, especially the farmland.

The scorpion stings occurred most often during the summer months, peaking in July and August (Figure 2), with 59.8\% between $6 \mathrm{pm}$ and 6 am.

As to the post-sting time (the time between the sting and a first consultation), the results showed that $67.3 \%$ of patients were able to receive medical attention in less than one hour. 


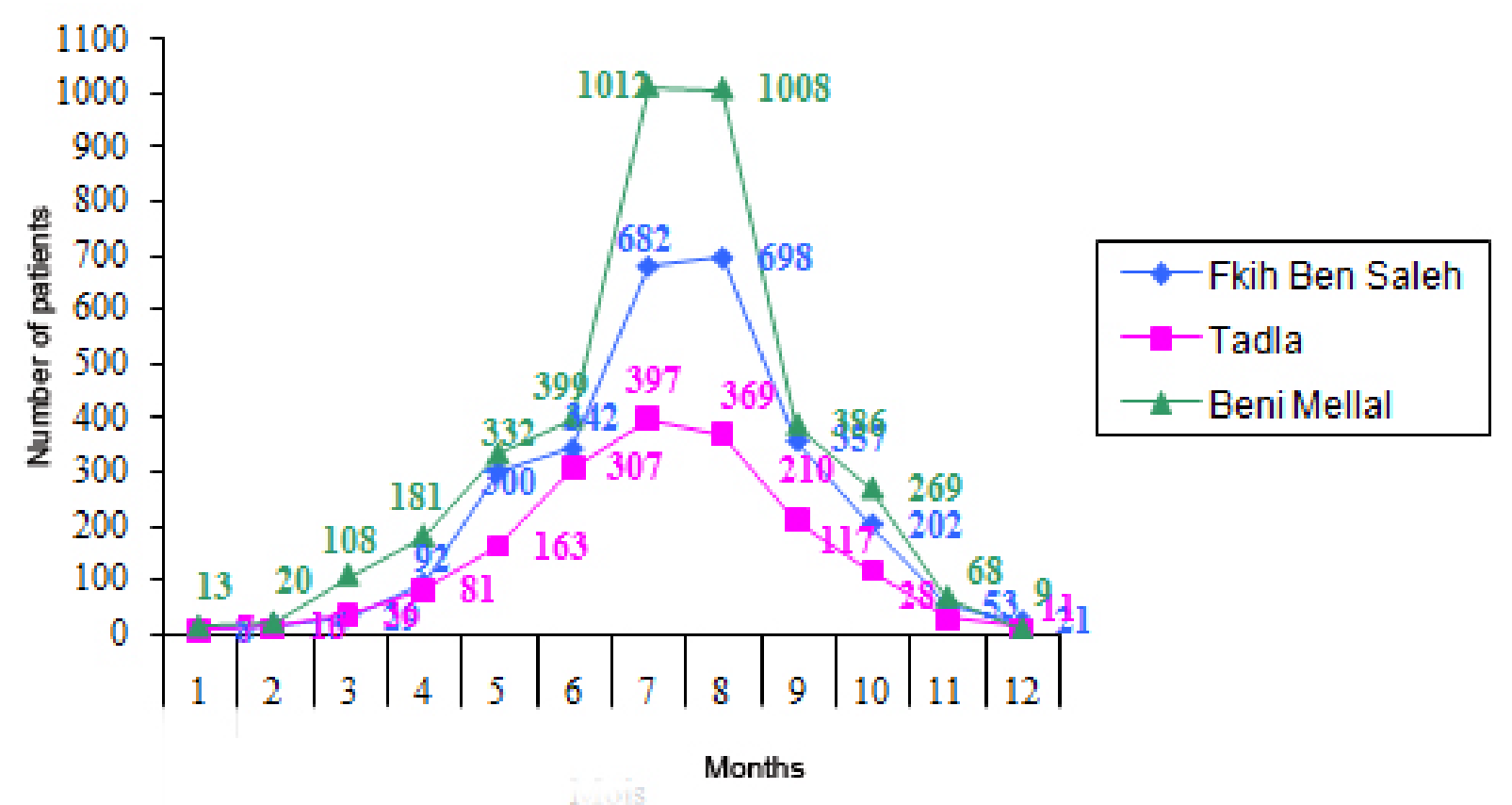

Figure 2. Distribution of scorpion stings cases by months in different health centers.

\section{Classification of Cases}

According to our analyses, $87.6 \%$ of stung victims came to a health center in Class I without a sign of seriousness; the patients in this class were only stung not envenomed. It should be noted that the Classes II (presence of one or more general signs) and III (cardiovascular, respiratory or neurological distresses) comprise 12.4\% of cases, which is not negligible compared to other regions in Morocco.

\section{The Evolution Characteristics}

In Table 2, we recorded the characteristics of two sub-groups of evolution (healings and death) for age and class of admission. 
Table 2. Characteristics of two groups of evolution

\begin{tabular}{|c|c|c|c|c|}
\hline & Evolution & Number & Test & $\mathbf{P}$ \\
\hline \multicolumn{5}{|l|}{ Age } \\
\hline$\leq 15$ years & $\begin{array}{l}\text { Favorable } \\
\text { Death }\end{array}$ & $\begin{array}{l}1389 \\
35\end{array}$ & \multirow{2}{*}{$\chi^{2}=84.5$} & \multirow{2}{*}{$\begin{array}{l}(p<0.001) \\
H S\end{array}$} \\
\hline$>15$ years & $\begin{array}{l}\text { Favorable } \\
\text { Death }\end{array}$ & $\begin{array}{l}3415 \\
0\end{array}$ & & \\
\hline \multicolumn{5}{|c|}{ Class of admission } \\
\hline Class I & $\begin{array}{l}\text { Favorable } \\
\text { Death }\end{array}$ & $\begin{array}{l}3891 \\
0\end{array}$ & \multirow{3}{*}{$\chi^{2}=236.46$} & \multirow{3}{*}{$\begin{array}{l}(p<0.001) \\
H S\end{array}$} \\
\hline Class II & $\begin{array}{l}\text { Favorable } \\
\text { Death }\end{array}$ & $\begin{array}{l}483 \\
21\end{array}$ & & \\
\hline Class III & $\begin{array}{l}\text { Favorable } \\
\text { Death }\end{array}$ & $\begin{array}{l}150 \\
14\end{array}$ & & \\
\hline
\end{tabular}

HS: significant difference at 0.001

This table reveals two highly significant links, firstly, between age classes and evolution $\left(\chi^{2}=84.5\right.$ and $\left.p<0.001\right)$ and, secondly, between admission classes and evolution $\left(\chi^{2}=236.46\right.$ and $\left.p<0.001\right)$. The statistical significance of this difference led us to perform further analysis by calculating the relative risk (Table 3 ).

Table 3. The relative risk of death by age and class of admission

\begin{tabular}{|c|c|c|c|c|c|}
\hline \multicolumn{2}{|l|}{ Variables } & Death & Favorable & RR & IC.95\% \\
\hline \multirow{4}{*}{ Class of admission } & Classes II and III & 35 & 633 & \multirow{2}{*}{7.147} & \multirow{2}{*}{$6.649-7.682$} \\
\hline & Class I & 0 & 3891 & & \\
\hline & Class III & 14 & 150 & \multirow{2}{*}{2.147} & \multirow{2}{*}{$1.065-4.326$} \\
\hline & Class II & 21 & 483 & & \\
\hline \multirow{2}{*}{ Age } & $\leq 15$ years & 35 & 1389 & \multirow{2}{*}{3.459} & \multirow{2}{*}{ 3.309-3.615 } \\
\hline & $>15$ years & 0 & 3415 & & \\
\hline
\end{tabular}

The results showed that the admission class determines the evolution of the envenomed patient. Indeed, the risk of death is seven times higher in patients who are admitted to Class II or III than in those who are admitted to Class I. 
These results also showed that the risk of death is 3.4 times higher among children aged $\leq 15$ years compared to older victims. This shows that age is a risk factor in determining the prognosis of patients. In fact, mortality was observed only among children younger than 15 years. Thus, children were redistributed into five groups to achieve more details on the specific fatality among them (Table 4).

Table 4. Specific fatality rate according to age group

\begin{tabular}{c|c|c|c|c}
\hline Age & $\begin{array}{c}\text { Number of } \\
\text { patients }\end{array}$ & $\begin{array}{c}\text { Number of } \\
\text { deaths }\end{array}$ & $\begin{array}{c}\text { Specific } \\
\text { lethality (\%) }\end{array}$ & Test \\
\hline $0-3$ & 337 & 14 & 4.15 & \\
$3-6$ & 452 & 11 & 2.43 & $\chi^{2}=22.98$ \\
$6-9$ & 364 & 7 & 1.92 & $(p<0.001)$ \\
$9-12$ & 456 & 3 & 0.65 & \\
$12-15$ & 389 & 0 & 0 & \\
\hline
\end{tabular}

These results showed that mortality was observed only in children less than 12 years with a maximum fatality rate among children age $\leq 3$ years. The analysis of these test results by $\chi^{2}$ gives a highly significant value of $22.98(p<0.001)$.

\section{DISCUSSION}

During this 6-year period, we assessed 8340 scorpion sting cases in Beni Mellal province, which represents an average incidence of $1.36 \%$.

The scorpions were especially active during the hottest months between $6 \mathrm{pm}$ and 6 am; the majority of cases of scorpion stings were recorded during the months of July and August in this study. The confluence of our data with those of the literature (6-11) emphasizes why the authorities and health personnel should intensify their efforts during this period.

The clinical signs differ according to patient age, geographic area and scorpion species (12).

In our series the children $\leq 15$ years accounted for $30.3 \%$ of stung patients while $100 \%$ of deaths were among children aged less than 12 years. Our data agree with the literature that the relationship between the venom doses injected and body 
weight of the victim is closely linked to emergence of signs of gravity; so the progress highly depends on the admission class (13-16).

Similar to findings reported in the literature, patients admitted to Class I represent 87.5\% (17-21). However, the Class II proportion was lower (8.8\% of cases) than those in the literature (22). The percentage of admission of Class III patients was $3.5 \%$.

\section{CONCLUSION}

Scorpion stings are very frequent in the province of Beni Mellal and constitute a genuine public health problem with a lethality rate of $0.42 \%$ that is higher than the national rate $(0.36 \%)$. Statistical analysis showed that the age $\leq 15$ years as well as admission Classes II and III are risk factors in stung patients.

Our work evaluated some indicators of follow-up, namely the morbidity and lethality due to scorpion sting, to assess the efficacy of the established strategy, which was confirmed by:

- the change in the population behavior;

- the health professionals' ability to differentiate between scorpion stings and envenomation cases;

- the considerable reduction in expenses due to the decisions of CAPM, which indicates that the communication, information and continuing education constitute the basis for any high-quality process.

\section{REFERENCES}

1. Soulaymani-Bencheikh R, Faraj Z, Semlali I, Khattabi A, Skalli S, Benkirane R, Badri M. Epidémiologie des piqûres de scorpion au Maroc. Rev Epidemiol Santé Publique. 2002;50(4):341-7.

2. Touloun O, Slimani T, Boumezzough A. Epidemiological survey of scorpion envenomation in southwestern Morocco. J Venom Anim Toxins. 2001;7(2):199-218.

3. Soulaymani-Bencheikh R, Soulaymani A, Semlali I, Tamim OK, Zemrour F, Eloufir $R$, Mokhtari A. Les piqûres et les envenimations scorpioniques au niveau de la population de Khouribga (Maroc). Bull Soc Patho Exot. 2005;98(1):36-40.

4. Soulaymani-Bencheikh R, Idrissi M, Tamim O, Semlali I, Mokhtari A, Tayebi M, Soulaymani A. Scorpion stings in one province of Morocco: epidemiological, clinical and prognosis aspects. J Venom Anim Toxins incl Trop Dis. 2007;13(2):462-71. 
5. Soulaymani-Bencheikh R, Semlali I, Ghani A, Badri M, Soulaymani A. Implantation et analyse d'un registre des piqûres de scorpion au Maroc. Revue Santé Publique. 2004;16(3):487-98.

6. Soulaymani-Bencheikh R, Soulaymani A, Charrab N, Semlali I, El Oufir G, Mokhtari A. Etude épidémiologique des piqûres et des envenimations scorpioniques (à propos de 1591 patients consultants à l'hôpital provincial de Beni Mellal). Mis en ligne le 15 Juillet 2007 sur le site de la Soc Méd Mil Nat Path. Faune flore. Available from: www.somednat.org/article.php3?id_article=42.

7. Al-Asmari AK and Al-Saif AA. Scorpion sting syndrome in a general hospital in Saudi Arabia. Saudi Med J. 2004;25(1):64-70.

8. Al-Sadoon MK, Jarrar BM. Epidemiological study of scorpion stings in Saudi Arabia between 1993 and 1997. J Venom Anim Toxins incl Trop Dis. 2003;9(1):5464.

9. Broglio N, Goyffon M. Les accidents d'envenimation scorpionique. Conc Méd. 1980;38:5615-22.

10. Goyffon M. Le scorpionisme en Afrique sub-saharienne. Bull Soc Patho Exot. 2002;95(3):191-3.

11. El Oufir R, Semlali I, Idrissi M, Soulaymani A, Benlarabi S, Khattabi A, Ait Moh M, Soulaymani Bencheikh R. Scorpion sting: a public health problem in El Kelaa des Sraghna (Morocco). J Venom Anim Toxins incl Trop Dis. 2008;14(2):258-73.

12. Mion G, Olive F, Hernandez E, Martin YN, Vieillefosse AS, Goyffon M. Action of venoms on blood coagulation: diagnosis of hemorrhagic syndromes. Bull Soc Pathol Exot. 2002;95(3):132-8.

13. Suhendan A, Ozcan O, Bora I. Epidemiological and clinical characteristics of scorpionism in children in Sanliurfa, Turkey. Toxicon. 2007;49(6):875-80.

14. De Roodt AR, Garcia SI, Salomon OD, Segre L, Dolab JA, Funes RF, De Titto EH. Epidemiological and clinical aspects of scorpionism by Tityus trivittatus in Argentina. Toxicon. 2003;41(8):971-7.

15. Pipelzadeha $\mathrm{MH}$, Jalali $\mathrm{A}$, Taraz $\mathrm{M}$, Pourabbas $\mathrm{R}$, Zaremirakabadi $A$. An epidemiological and a clinical study on scorpionism by the Iranian scorpion Hemiscorpius lepturus. Toxicon. 2007;50(7):984-92.

16. El Aminn EO, Berair R. Piqûres de scorpion chez l'enfant. Expérience saoudienne. Arch Pediatr. 1995;2(8):766-73. 
17. Charrab N, Semlali I, Soulaymani A, Mokhtari A, El Oufir R, Soulaymani Bencheikh R. Les caractéristiques épidémiologiques du scorpionisme dans la province de Beni Mellal (2002-2004). Rev Biol Biotech. 2007;6(2):36-9.

18. Hammoudi-Triki D, Ferquel E, Robbe-Vincent A, Bon C, Choumet V, LarabaDjebari F. Epidemiological data, clinical admission gradation and biological quantification by ELISA of scorpion envenomations in Algeria: effect of immunotherapy. Trans R Soc Trop Med Hyg. 2004;98(4):240-50.

19. Abroug F, Elatrous S, Nouira S, Haguiga H, Touzi N, Bouchoucha S. Serotherapy in scorpion envenomation: a randomised controlled trial. The Lancet. 1999;354(9182):906-9.

20. Diaz P, Chowell G, Ceja G, D'Auria TC, Lloyd RC, Castillo-Chavez C. Pediatric electrocardiograph abnormalities following Centruroides limpidus tecomanus scorpion envenomation. Toxicon. 2005;45(1):27-31.

21. Osnaya-Romero N, Medina-Hernandez TJ, Flores-Hernandez SS, Leon-Rojas G. Clinical symptoms observed in children envenomated by scorpion stings, at the children's hospital from the state of Morelos, Mexico. Toxicon. 2001;39(6):781-5.

22. Chowell G, Diaz-Duenas P, Bustos-Saldana R, Mireles AA, Fet V. Epidemiological and clinical characteristics of scorpionism in Colima, Mexico (20002001). Toxicon. 2006;47(7):753-8. 